\title{
Z

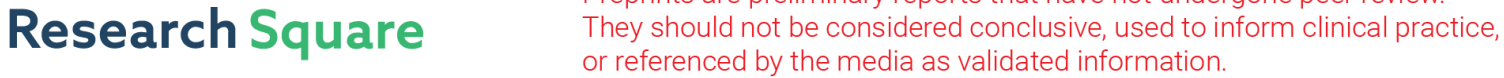 \\ Cell Banking of HEK293T Cell Line for Clinical-Grade Lentiviral Particles Manufacturing
}

\section{Unai Perpiña}

Universitat de Barcelona Facultat de Medicina i Ciencies de la Salut

\section{Cristina Herranz}

Universitat de Barcelona Facultat de Medicina i Ciencies de la Salut

\section{Raquel Martin-Ibañez}

Universitat de Barcelona, Facultat de Medicina i Ciencies de la Salut

\section{Anna Boronat}

Hospital Clínic de Barcelona

\section{Felipe Chiappe}

Universitat de Barcelona, Facultat de Medicina i Ciencies de la Salut

\section{Verónica Monforte}

Universitat de Barcelona Facultat de Medicina i Ciencies de la Salut

\section{Gemma Orpella-Arecet}

Universitat de Barcelona Facultat de Medicina i Ciencies de la Salut

\section{Ester González}

Universitat de Barcelona Facultat de Medicina i Ciencies de la Salut

\section{Myriam Olive}

Universitat de Barcelona Facultat de Medicina i Ciencies de la Salut

\section{Maria Castella}

Hospital Clinic de Barcelona

\section{Guillermo Suñe}

Hospital Clínic de Barcelona

\section{Alvaro Urbano}

Hospital Clinic de Barcelona

\section{Julio Delgado}

Hospital Clínic de Barcelona

\section{Manel Juan}

Hospital Clínic de Barcelona

Josep M. Canals ( $\square$ jmcanals@ub.edu )

Universitat de Barcelona Facultat de Medicina i Ciencies de la Salut https://orcid.org/0000-0001-68297670 
Research

Keywords: ATMP, Good Manufacturing Practices, Cell therapy, Gene therapy, HEK293T, CAR-T, lentivirus Posted Date: August 13th, 2020

DOI: https://doi.org/10.21203/rs.3.rs-54098/v1

License: (c) (i) This work is licensed under a Creative Commons Attribution 4.0 International License. Read Full License 


\section{Abstract}

Background: Cell banks have been widely used to preserve cell properties as well as to record and control cell line access in research. However, the generation of cell banks involved in the manufacturing of Advanced therapy medicinal products such as cell or gene therapy products must comply with the current Good Manufacturing Practice regulation. Similarly, the quality of those cell lines used as starting materials in viral-vector manufacturing processes must be also evaluated.

Methods: Three batches of both Master Cell Bank and Working Cell Bank of the HEK293T cell line were manufactured under the current Good Manufacturing Practices regulation. Quality control test were performed according to the product specifications. The process validation includes previous qualification of the manufacturing personnel by performing simulation tests as well as the continuous measure of environmental parameters during manufacturing such as air particles and microorganism. Cell number and viability of cryopreserved cells were periodically measured in order to define the stability of these cellular products.

Results: All batches of Master Cell Bank and Working Cell Bank fulfilled the acceptance criteria of their specifications showing the robustness and homogeneity of the processes. In addition, both Master and Working cell bank maintain the defined viability and cell number 37 months after cryopreservation.

Conclusions: Manufacturing cell banks under Good Manufacturing Practices regulation for its use as raw material or final cellular product is feasible. HEK293T cell banks have been used to manufacture clinicalgrade lentiviral particles for Chimeric Antigen Receptor T-cell based clinical trials.

\section{Background}

Advanced Therapies Medicinal Products (ATMPs) such as cell therapy, gene therapy and tissue engineering ${ }^{1,2}$ have emerged as serious candidates for the treatment of diseases, to date, without effective treatment. This is the case of Alofisel ${ }^{\circledR}$, a cell therapy product based on adipose-derived mesenchymal stem cells to treat perianal fistulas in Crohn's disease, ${ }^{3}$ and Holoclar ${ }^{\circledR}$, a product catalogued as a tissue engineering product used in corneal diseases which is based on the generation of fibrin membranes coated with a population of corneal tissue cells among which are limbal stem cells. ${ }^{4}$

In addition, clinical trials based on ex vivo and in vivo gene therapies have increased due to its wide potential in monogenic disorders such as cystic fibrosis, adenosine deaminase deficiency (ADA-SCID) or haemophilia B (factor IX deficiency) among others. ${ }^{5}$ European Medicines Agency (EMA) and Food and Drug Administration (FDA) regulatory entities have recently approved several gene derived ATMPs. This is the case of Zolgensma ${ }^{\circledR}$, used for the treatment of spinal muscular atrophy (SMA) based on the in vivo administration of adeno-associated viruses (AAVs), which insert a functional version of survival motor neuron 1 (SMN1) gene; ${ }^{6,7}$ and Zynteglo ${ }^{\circledR}$, an autologous ex vivo gene therapy for beta thalassemia based 
on the use of lentiviruses to insert a functional hemoglobin subunit beta (HBB) gene in the hematopoietic stem cells of the patient. ${ }^{8}$

Chimeric Antigen Receptor (CAR) T-cell therapy might be considered as the most revolutionary ex vivo gene-therapy in the oncology field because allows to target specific surface antigens of a wide range of tumour cell populations. Anti-CD19 CAR T-cells for relapsed/refractory B-ALL patients, the first cancer gene-therapy approved on August 2017 by the FDA, is being used worldwide because of its impressive clinical outcomes. ${ }^{9-11}$ Anti-CD30 CAR T-cells and Anti-BCMA CAR T-cells are also promising therapies based on CAR T-cell technology. ${ }^{12,13}$

Most of ATMP-scientific knowledge as well as the product development during the early clinical stages (Phase I/II) is generated in academic institutions, far from the pharmaceutical industry. ${ }^{14}$ Thus, academic institutions should understand the regulation involved in ATMP manufacturing in order to achieve the transition from basic research to the clinic. Good Manufacturing Practices (GMP) are mandatory for all manufacturing sites dedicated to ATMP manufacturing, even academic institutions. Given the nature and complexity of these products, it is of crucial importance not only to develop new safety and effective products, but also to provide high quality products by guaranteeing the robustness and homogeneity of the products generated. ${ }^{15}$ Therefore, manufacturing procedures should be validated according to the GMP and, for this reason, before starting the manufacturing process a deep evaluation of the whole process from its raw materials to the final product as well as product specifications of starting materials is required. Here we presented the academic GMP generation of a Master Cell Bank (MCB) and Working Cell Bank (WCB) of the HEK293T at Creatio, the production and validation center of advanced therapies at the University of Barcelona. HEK293T is a cell widely used in adherent cell culture as a consolidated model of viral-vector production thanks to its high transfectability. MCB and WCB were used as a packaging cell line to obtain GMP-grade lentiviruses for several clinical trials based on CAR T-cell therapy. This is the case of both phase I clinical trial CART19-BE-01 (EudraCT Number: 2016-002972-29) and phase II clinical trial CART19-BE-02 (EudraCT Number: 2019-003038-17) based on anti-CD19 CAR T-cell therapy, as well as the phase I clinical trial based on anti-BCMA CAR T-Cell therapy (EudraCT Number: 2019-001472-11).

This GMP-grade cell banking approach does not only become a guide for those academic centers willing to generate GMP-grade lentiviruses, but it is also a reference to generate other different viral vectors.

\section{Methods}

\section{Quality System}

Creatio Quality System operates under the current GMP regulation and is authorized by Spanish Agency of Medicines and Medical Devices (PE010-1570, AEMPS, Spain). Specific organization chart is implemented at Creatio. Functions and responsibilities of every key personnel and technician are clearly defined and documented. Specific documentary management system is implemented including: risk 
assessment approaches, change control of documentation, incidences and nonconformities record, calibration, validation and qualification annual strategy, audit program, personnel training program, preventive maintenance system, reagents and starting materials record and traceability, quality control management, manufacturing management, batch certification and release system.

\section{Facility and Equipment}

Creatio facility is an academia center of the University of Barcelona dedicated to investigational ATMPs validation and manufacturing for their use in phase I/II clinical trials. The facility has $4 \mathrm{~B}$-grade cleanrooms in which all procedures are performed in a A-grade laminar flow cabinet. MCB and WCB of the HEK293T cell line (CRL-11268; ATCC, Mansassa, VA, USA; obtained under License Agreement between The Rockefeller University and Hospital Clínic de Barcelona; 17th October, 2016) were performed in the cleanroom dedicated for cell therapy. The access to this cleanroom consists of an entrance to the predressing room (D-grade), a pre-dressing room (C-grade), a dressing room (B-grade) and a distributor (Bgrade) (Fig. 1). Adjacent rooms have a differential pressure of 10-15 $\mathrm{Pa}$ reaching $50 \mathrm{~Pa}$ in the grade $\mathrm{B}$ cleanroom. Creatio facility has two storage rooms (D-grade) and a product conditioning D-grade rooms. Pressure, temperature and humidity are continuously regulated and monitored by a specific software control (Controlli Delta Spain, Barcelona, Spain). The facility is validated once a year according to specific procedure of validation management. Equipment is qualified and calibrated according to an annual planning. Thermic equipment such as incubators, refrigerators, freezers, ultra-freezers, nitrogen tank, as well as $\mathrm{CO}_{2}$ levels of the incubators are continuously monitored by a specific software control (Sirius, Nirco, Rubí, Spain).

\section{HEK293T cell culture}

HEK293T cells were thawed at $37^{\circ} \mathrm{C}$ using a thermoblock for 2 min and transferred to a tube with cell culture medium containing $90 \%$ of DMEM (Thermo Fisher Scientific, Walthman MA, USA) and $10 \%$ of fetal bovine serum (FBS) (Thermo Fisher Scientific). Subsequently, cells were centrifuged (1250 rpm, 5 minutes), the supernatant was removed and cells were resuspended in cell culture medium to proceed with Trypan blue-based cell counting. Cells were seeded in a sterile and pyrogen-free flask at a density of $1 \times 10^{6}$ cells $\times 25 \mathrm{~cm}^{2}$ and incubated at $37^{\circ} \mathrm{C} / 5 \% \mathrm{CO}_{2}$ for $3-4$ days until cells reached $80 \%$ of confluence. To carry out cell passages, culture medium was eliminated, and cells were washed with phosphatebuffered saline (PBS) (Thermo Fisher Scientific). TrypLE ${ }^{\text {TM }}$ (Thermo Fisher Scientific) was added and incubated for $1 \mathrm{~min}$ in order to detach cells from the flask. Once detached, cells were transferred to a tube containing medium and centrifuged (1250 rpm, $5 \mathrm{~min}$ ). Cells were counted, centrifuged again (1250 rpm,

$5 \mathrm{~min}$ ) and seeded in as many flasks of 25 or $75 \mathrm{~cm}^{2}$ as necessary at a density of $1 \cdot 10^{6}$ cells $\cdot 25 \mathrm{~cm}^{2}$. Cell passages were made to reach more than $200 \cdot 10^{6}$ cells for the MCB and $1000 \cdot 10^{6}$ for the WCB.

\section{HEK293T cryopreservation}

Once the cell number was reached, cells were centrifuged (1250 rpm, $5 \mathrm{~min}$ ) and the resulting pellet was resuspended in cryopreservation medium to achieve a density of $10 \cdot 10^{6}$ cells $/ \mathrm{ml}$ for MCB and $20 \cdot 10^{6}$ 
cells/ml for WCB. Cryopreservation medium was composed of $95 \%$ of cell culture medium (90\% DMEM, $10 \%$ FBS) and $5 \%$ of DMSO (Scharlab, Setmenat, Spain). Cryotubes were properly labelled and filled with $1 \mathrm{ml}$ of the proper concentration. Cryotubes were transported from the cleanroom area to the cryopreservation area and temperature was monitored during transport. Cryopreservation was carried out in a controlled-rate freezer (Criomed ${ }^{\mathrm{T}}{ }^{\mathrm{M}}$, Thermo Fisher Scientific) following a freezing program that lowers the temperature $1{ }^{\circ} \mathrm{C} /$ minute. The resulting cryotubes were transferred to a gas phase nitrogen tank $180^{\circ} \mathrm{C} \pm 20^{\circ} \mathrm{C}$.

\section{Personnel training and validations}

Personnel training program is continuously ongoing at Creatio. Manufacturing personnel is also qualified once every 6 months with simulation tests of ongoing processes. Three consecutive simulation tests were performed by production personnel involved in the MCB and WCB manufacturing before starting. Tryptic Soy Broth media (TSB) was used to carry out simulation tests (Becton Dickinson, Madrid, Spain). Simulation tests were designed with the same materials and equipment of MCB and WCB processes, as well as considering the steps of the whole processes and emphasizing the worst-case stages. Simulation tests were continuously monitored for microorganisms and particles according to GMP standards. For the demonstration of the maintenance of the aseptic conditions during the simulation process, sampling points were established at the beginning of the process (negative control) and at the end (simulation of the final product).

\section{Environment monitoring}

A laser particle counter (CLiMET, Redlands, CA, USA) was used to monitor air particles in the cabinet (Agrade) during the manufacturing process as well as during the simulation tests. 3520 particles equal or greater than $0.5 \mu \mathrm{m}$ per $\mathrm{m}^{3}$ were established as the maximum permitted number of particles in A-grade. 20 particles equal or greater than $5 \mu \mathrm{m}$ per $\mathrm{m}^{3}$ were established as the maximum permitted number of particles in A-grade. Both acceptance criteria were established according to the current GMP regulation. ${ }^{15}$

Settle plates (Becton Dickinson) were used to monitor microorganism (bacteria and fungi) in the cabinet (A-grade) during the manufacturing process as well as during the simulation tests. In addition, glove prints from personnel working in A-grade were submitted for microbiological analysis (Becton Dickinson) after every working day. Acceptance criteria of less than 1 colony forming units were established in accordance with current GMP regulation. ${ }^{15}$

\section{MCB and WCB process validation}

Starting from one cryovial of HEK293T cell line, cells were thawed and split in three HEK293T populations which were independently expanded in order to obtain three cell stocks forming the MCB. Each batch of HEK293T cell line was expanded until reaching $200 \cdot 10^{6}$ of cells. Every batch of MCB was composed of at least 20 cryotubes/batch summing $\geq 60$ cryotubes of MCB. Quality control tests were analyzed for every MCB batch. Three consecutive and independent batches of WCB were performed. HEK293Tcells from MCB were thawed and expanded until reaching $1000 \cdot 10^{6}$ of cells. Every batch of WCB was composed by 
at least 50 cryotubes/batch summing $\geq 150$ cryotubes of WCB. Quality control tests were analyzed for every WCB batch.

\section{Sterility Test and growth promotion test}

Cell culture medium and TSB were submitted to a growth promotion test according to Chap. 2.6.1 of the European Pharmacopeia in order to ensure that TSB media met the proper characteristics for sterility methods.

Sterility tests of TSB, MCB samples and WCB samples were performed according to the sterility method by direct inoculation described in Chap. 2.6.1 and 2.2.27 of the European Pharmacopeia. ${ }^{16}$

\section{Mycoplasma Test}

Venor ${ }^{\circledR}$ GeM qOneStep kit (Minerva Biolabs $\AA$, Berlin, Germany) was used to test Mycoplasma of TSB samples, MCB samples and WCB samples. The method is based on the amplification and detection of the conserved region 16S rRNA and fulfil with the method described in Chap. 2.6.7 of the European Pharmacopeia. ${ }^{16}$

\section{Karyotype test}

Karyotype was determined by G band staining. HEK293T were seeded and incubated until a confluence of $80 \%$ was observed. $12 \mu$ of KaryoMAX ${ }^{\text {TM }}$ Colcemid $^{\text {TM }}$ (Thermo Fisher Scientific) were diluted in $6 \mathrm{ml}$ of DMEM. Subsequently, $6 \mathrm{ml}$ of KaryoMAX ${ }^{\mathrm{TM}}$ Colcemid $^{\mathrm{TM}}$ dilution were added to the cell culture and incubated $37^{\circ} \mathrm{C} / 5 \% \mathrm{CO}_{2}$ for an hour.Cell culture medium was removed and $3 \mathrm{ml}$ of PBS (Thermo Fisher Scientific) was added to the plate in order to wash cells. After removing PBS from the plate, $1 \mathrm{ml}$ of TrypLE $^{\mathrm{TM}}$ (Thermo Fisher Scientific) was added for 1 minute at $37^{\circ} \mathrm{C} .5 \mathrm{ml}$ of culture medium was added, and cells were collected. Cells were centrifuged for 5 minutes at $1250 \mathrm{rpm}$. After removing the supernatant, the cellular pellet was washed with PBS and centrifuged again for 5 minutes at $1250 \mathrm{rpm}$. Gently, $10 \mathrm{ml}$ of KaryoMAx $x^{\mathrm{TM}} \mathrm{KCl} 0.075 \mathrm{M}$ at $37^{\circ} \mathrm{C}$ were added to the cells. After 10 minutes of incubation at $37^{\circ} \mathrm{C}$, cells were fixed with Carnoy fixation solution.

\section{Adventitious viruses test}

Adventitious viruses test was based on the determination of cytopathic effect. HEK293T cell line samples from MCB and WCB were shacked with 0.2 and $3 \mathrm{~mm}$ stainless steel beads. Cell homogenate was centrifuged (1250 rpm, $5 \mathrm{~min}, 4^{\circ} \mathrm{C}$ ) and $0.9 \mathrm{ml}$ of supernatant was added to MR5, VERO and RD cell lines culture (Vircell, Granada, Spain) and incubated at $35-37^{\circ} \mathrm{C}$. The cell culture was analyzed 14 days after the inoculation. Positive and negative controls were analyzed concomitantly. Real Time (RT)-PCR for Enterovirus was performed in samples with no cytopathic effect.

\section{In Process Controls (IPCs): Cell Morphology, cell confluence and viability}


Cell morphology, cell confluence and cell viability were established as IPCs during the whole processes of MCB and WCB generation. Morphology inspection of HEK293T cell line as well as cell confluence was carried out visually under microscope. Trypan blue exclusion test was used in every cell passage step to test cell viability, being $80 \%$ the minimal criteria.

\section{Cell line Identification}

The following Short Tandem Repeat (STR) profile of the HEK293T cell line was analyzed: Amelogenin: X,CSF1PO: 11, 12; D13S317: 12, 14; D16S539: 9, 13; D5S818: 8, 9; D7S820: 11; TH01: 7, 9.3; TPOX: 11; vWA: 16, 18, 19.

\section{MCB/WCB stability after cryopreservation: Viability and cell number}

Trypan blue exclusion assay of each batch of MCB and WCB was used to test viability of both MCB and WCB after cryopreservation in order to ensure the proper cryopreservation conditions being equal or greater than $50 \%$ the acceptance criteria of the viability test after thawing.

An ongoing stability program was established during a period of 37 months after WCB generation in order to determine the proper storage conditions of MCB and WCB. Trypan blue exclusion assay was used to test viability and cell number of WCB during the on-going stability program.

\section{Results}

\section{MCB process validation}

MCB validation was performed following the workflow shown in Fig. 2A. Environmental controls as well as in process control (IPCs) were carried out during the whole procedure of MCB generation (Table 1). No incidence was detected, and regarding the specifications of the MCB, all three batches met the acceptance criteria (Table 2). Sterility tests indicated that all three batches were negative for bacterial and fungal growth. Mycoplasma tests indicated absence of mycoplasma in all three batches. Morphology test by visual inspection showed adherent cells with presence of fine extensions. Complex karyotypes were detected in all batches, being coherent with the bibliography. ${ }^{17,18}$ Thawing viability tests were over $90 \%$ fulfilling the specifications. In general terms, MCB met the acceptance criteria for all specifications, thereby demonstrating that the process was robust and homogenous. 
Table 1

Environmental parameters of MCB validation. Table summarizing the environmental results obtained in the three MCB batches. Air particles in cabinet (A grade) were measured during each step of the MCB procedure. Particles equal or greater than $0.5 \mu \mathrm{m}$ fulfilled the acceptance criteria.

Particles equal or greater than $5 \mu \mathrm{m}$ fulfilled the acceptance criteria. Gloves of the operator working in cabinet (A grade) were monitored during each step of the MCB procedure. No microorganisms were detected, fulfilling the acceptance criteria. Environmental microorganisms were monitored during each step of MCB procedure by using settle plates in cabinet (A grade). No microorganisms were detected fulfilling the acceptance criteria.

\begin{tabular}{|lllll|}
\hline Environmental Parameters & Culture Day & Batch code: & Batch code: & Batch code: \\
\hline$\geq 0.5 \mu \mathrm{m}$ particles $/ \mathrm{m}^{3}$ & MCB-HE-01 & MCB-HE-02 & MCB-HE-03 \\
\hline & HEK293T Thawing & Pass & Pass & Pass \\
\hline 1st passage & Pass & Pass & Pass \\
\hline 2nd passage & Pass & Pass & Pass \\
\hline MCB Generation & Pass & Pass & Pass \\
\hline Glove Print UFC & HEK293T Thawing & Pass & Pass & Pass \\
\hline 1st passage & Pass & Pass & Pass \\
\hline 2nd passage & Pass & Pass & Pass \\
\hline MCB generation & Pass & Pass & Pass \\
\hline HEK293T Thawing & 0 & 0 & 0 \\
\hline 1st passage & 0 & 0 & 0 \\
\hline 2nd passage & 0 & 0 & 0 \\
\hline MCB generation & 0 & 0 & 0 \\
\hline HEK293T Thawing & 0 & 0 & 0 \\
\hline 1st passage & 0 & 0 & 0 \\
\hline 2nd passage & 0 & 0 & 0 \\
\hline MCB generation & 0 & 0 & 0 \\
\hline & & 0 & 0 & 0 \\
\hline
\end{tabular}


Table 2

MCB specifications. Table summarizing the results obtained in the three MCB batches. All specifications of the MCB batches fulfilled the acceptance criteria.

\begin{tabular}{|c|c|c|c|c|c|}
\hline Parameter & Method & $\begin{array}{l}\text { Acceptance } \\
\text { Criteria }\end{array}$ & MCB-HE-01 & MCB-HE-02 & MCB-HE-03 \\
\hline Morphology & $\begin{array}{l}\text { Visual } \\
\text { Inspection }\end{array}$ & $\begin{array}{l}\text { Adhered cells } \\
\text { with presence } \\
\text { of fine } \\
\text { extensions }\end{array}$ & $\begin{array}{l}\text { Adhered cells } \\
\text { with presence } \\
\text { of fine } \\
\text { extensions }\end{array}$ & $\begin{array}{l}\text { Adhered cells } \\
\text { with presence } \\
\text { of fine } \\
\text { extensions }\end{array}$ & $\begin{array}{l}\text { Adhered cells } \\
\text { with presence } \\
\text { of fine } \\
\text { extensions }\end{array}$ \\
\hline \multirow[t]{10}{*}{ Identification } & \multirow[t]{10}{*}{ PCR } & Presence of: & $8 / 9$ & $8 / 9$ & $8 / 9$ \\
\hline & & D5S818: 8,9 & $12 / 14$ & $12 / 14$ & $12 / 14$ \\
\hline & & $\begin{array}{l}\text { D13S317: } \\
1214\end{array}$ & 11 & 11 & 11 \\
\hline & & 11 & $9 / 13$ & $9 / 13$ & $9 / 13$ \\
\hline & & & 16/18/19 & $16 / 18 / 19$ & $16 / 18 / 19$ \\
\hline & & vWA 161819 & $7 / 9.3$ & $7 / 9.3$ & $7 / 9.3$ \\
\hline & & TH01.702 & $\mathrm{x}$ & $x$ & $x$ \\
\hline & & & 11 & 11 & 11 \\
\hline & & TPOX:11 & $11 / 12$ & $11 / 12$ & $11 / 12$ \\
\hline & & CSF1PO: 11,12 & & & \\
\hline Sterility & $\begin{array}{l}\text { Eu. Ph } \\
2.6 .1\end{array}$ & Sterile & Sterile & Sterile & Sterile \\
\hline Mycoplasma & $\begin{array}{l}\text { Eu. Ph } \\
2.6 .7\end{array}$ & Absent & Absent & Absent & Absent \\
\hline Karyotype & $\begin{array}{l}\text { G-Band } \\
\text { Staining }\end{array}$ & Informative & Complex & Complex & Complex \\
\hline $\begin{array}{l}\text { Adventitious } \\
\text { viruses }\end{array}$ & $\begin{array}{l}\text { Internal } \\
\text { method }\end{array}$ & $\begin{array}{l}\text { Absence of } \\
\text { cytopathic } \\
\text { effect }\end{array}$ & Absence & Absence & Absence \\
\hline $\begin{array}{l}\text { Viability } \\
\text { after } \\
\text { thawing }\end{array}$ & $\begin{array}{l}\text { Trypan } \\
\text { Blue } \\
\text { Assay }\end{array}$ & $\geq 50.0 \%$ & $91.9 \%$ & $96.9 \%$ & $93.8 \%$ \\
\hline
\end{tabular}

\section{WCB process validation}

WCB validation was performed following the workflow shown in Fig. 2B. Environmental controls as well as the IPCs were carried out during the whole processes of WCB (Table 3). No incidence was detected, and all three batches fulfilled their acceptance criteria. Regarding the specifications of the WCB, all three batches met the acceptance criteria (Table 4). Sterility tests indicated that all three batches were negative for bacterial and fungal growth. Mycoplasma tests indicated absence of mycoplasma in all three 
batches. Morphology test by visual inspection showed adherent cells with presence of fine extensions. Complex karyotypes were detected in all batches, being coherent with the bibliography. ${ }^{17,18}$ Thawing viability tests were over $90 \%$ fulfilling the specifications. In general terms, WCB met the criteria and the process was robust and homogenous.

Table 3

Environmental parameters of WCB validation. Table summarizing the environmental results obtained in the three WCB batches. Air particles in cabinet (A grade) were measured during each step of the WCB procedure. Particles equal or greater than $0.5 \mu \mathrm{m}$ fulfilled the acceptance criteria.

Particles equal or greater than $5 \mu \mathrm{m}$ fulfilled the acceptance criteria. Gloves of the operator working in cabinet (A grade) were monitored during each step of the WCB procedure. No microorganisms were detected, fulfilling the acceptance criteria. Environmental microorganisms were monitored during each step of WCB procedure by using settle plates in cabinet (A grade). No microorganisms were detected fulfilling the acceptance criteria.

\begin{tabular}{|c|c|c|c|c|}
\hline \multirow[t]{2}{*}{ Environmental Parameters } & \multirow[t]{2}{*}{ Culture Day } & Batch code: & Batch code: & Batch code: \\
\hline & & MCB-HE-01 & MCB-HE-02 & MCB-HE-03 \\
\hline \multirow{3}{*}{$\geq 0.5 \mu \mathrm{m}$ particles $/ \mathrm{m}^{3}$} & MCB Thawing & Pass & Pass & Pass \\
\hline & 1st passage & Pass & Pass & Pass \\
\hline & WCB Generation & Pass & Pass & Pass \\
\hline \multirow[t]{3}{*}{$\geq 5 \mu \mathrm{m}$ particles $/ \mathrm{m}^{3}$} & MCB Thawing & Pass & Pass & Pass \\
\hline & 1st passage & Pass & Pass & Pass \\
\hline & WCB generation & Pass & Pass & Pass \\
\hline \multirow[t]{3}{*}{ Glove Print UFC } & MCB Thawing & 0 & 0 & 0 \\
\hline & 1st passage & 0 & 0 & 0 \\
\hline & WCB generation & 0 & 0 & 0 \\
\hline \multirow[t]{3}{*}{ Settle plates UFC } & HEK293T Thawing & 0 & 0 & 0 \\
\hline & 1st passage & 0 & 0 & 0 \\
\hline & WCB generation & 0 & 0 & 0 \\
\hline
\end{tabular}


Table 4

WCB specifications. Table summarizing the results obtained in the three WCB batches. All specifications of the WCB batches fulfilled the acceptance criteria.

\begin{tabular}{|c|c|c|c|c|c|}
\hline Parameter & Method & $\begin{array}{l}\text { Acceptance } \\
\text { Criteria }\end{array}$ & WCB-HE-01 & WCB-HE-02 & WCB-HE-03 \\
\hline Morphology & $\begin{array}{l}\text { Visual } \\
\text { Inspection }\end{array}$ & $\begin{array}{l}\text { Adhered cells } \\
\text { with presence } \\
\text { of fine } \\
\text { extensions }\end{array}$ & $\begin{array}{l}\text { Adhered cells } \\
\text { with presence } \\
\text { of fine } \\
\text { extensions }\end{array}$ & $\begin{array}{l}\text { Adhered cells } \\
\text { with presence } \\
\text { of fine } \\
\text { extensions }\end{array}$ & $\begin{array}{l}\text { Adhered cells } \\
\text { with presence } \\
\text { of fine } \\
\text { extensions }\end{array}$ \\
\hline \multirow[t]{10}{*}{ Identification } & \multirow[t]{10}{*}{ PCR } & Presence of: & $8 / 9$ & $8 / 9$ & $8 / 9$ \\
\hline & & D5S818: 8,9 & $12 / 14$ & $12 / 14$ & $12 / 14$ \\
\hline & & $\begin{array}{l}\text { D13S317: } \\
1214\end{array}$ & 11 & 11 & 11 \\
\hline & & ח7cosn. 11 & $9 / 13$ & $9 / 13$ & $9 / 13$ \\
\hline & & & 16/18/19 & $16 / 18 / 19$ & $16 / 18 / 19$ \\
\hline & & WWA 161819 & $7 / 9.3$ & $7 / 9.3$ & $7 / 9.3$ \\
\hline & & TH01. 793 & $x$ & $x$ & $\mathrm{x}$ \\
\hline & & 1170 . 1, & 11 & 11 & 11 \\
\hline & & TPOX:11 & $11 / 12$ & $11 / 12$ & $11 / 12$ \\
\hline & & CSF1PO: 11,12 & & & \\
\hline Sterility & $\begin{array}{l}\text { Eu. Ph } \\
2.6 .1\end{array}$ & Sterile & Sterile & Sterile & Sterile \\
\hline Mycoplasma & $\begin{array}{l}\text { Eu. Ph } \\
2.6 .7\end{array}$ & Absent & Absent & Absent & Absent \\
\hline Karyotype & $\begin{array}{l}\text { G-Band } \\
\text { Staining }\end{array}$ & Informative & Complex & Complex & Complex \\
\hline $\begin{array}{l}\text { Adventitious } \\
\text { viruses }\end{array}$ & $\begin{array}{l}\text { Internal } \\
\text { method }\end{array}$ & $\begin{array}{l}\text { Absence of } \\
\text { cytopathic } \\
\text { effect }\end{array}$ & Absence & Absence & Absence \\
\hline $\begin{array}{l}\text { Viability } \\
\text { after } \\
\text { thawing }\end{array}$ & $\begin{array}{l}\text { Trypan } \\
\text { Blue } \\
\text { Assay }\end{array}$ & $\geq 50.0 \%$ & $97 \%$ & $94.4 \%$ & $96.4 \%$ \\
\hline
\end{tabular}

\section{Simulation tests Validation}

Before starting the validation process, production personnel were subjected to an aseptic validation by reproducing the entire steps of the MCB and WCB process with TSB medium. All samples obtained from simulation test batches were sterile throughout the simulation process (Table 5). According to the environmental monitoring during the simulation processes, print-gloves and settle plates fulfil with the acceptance criteria for A-grade (Tables 5), as well as no viable particles were detected during the 
simulation processes meeting the acceptance criteria (Table 5). These results indicate that the personnel were apt for the accomplishment of aseptic productions and were not focus of contamination.

Table 5

Simulation tests results. Table summarizing the results obtained in the three simulation test batches.

Particles equal or greater than $0.5 \mu \mathrm{m}$ and particles equal or greater than $5 \mu \mathrm{m}$ in cabinet (A grade) fulfilled the acceptance criteria. Gloves of the operator working in cabinet (A grade) as well as environmental microorganisms in cabinet (A grade) monitored during each step of the simulation test. No microorganisms were detected fulfilling the acceptance criteria. No microorganisms were detected fulfilling the acceptance criteria. Samples of the TSB used in the entire procedure of simulation test was submitted to sterility test.

\begin{tabular}{|c|c|c|c|c|}
\hline \multirow[t]{2}{*}{ Parameter } & \multirow[t]{2}{*}{ Culture Day } & $\begin{array}{l}\text { Batch } \\
\text { code: }\end{array}$ & $\begin{array}{l}\text { Batch } \\
\text { code: }\end{array}$ & $\begin{array}{l}\text { Batch } \\
\text { code: }\end{array}$ \\
\hline & & MF-HE-01 & MF-HE-02 & MF-HE-03 \\
\hline \multirow{4}{*}{$\begin{array}{l}\geq 0.5 \mu \mathrm{m} \\
\text { particles } / \mathrm{m}^{3}\end{array}$} & 1st entrance & Pass & Pass & Pass \\
\hline & 2nd entrance & Pass & Pass & Pass \\
\hline & 3rd entrance & Pass & Pass & Pass \\
\hline & 4th entrance & Pass & Pass & Pass \\
\hline \multirow[t]{4}{*}{$\geq 5 \mu \mathrm{m}$ particles $/ \mathrm{m}^{3}$} & 1st entrance & Pass & Pass & Pass \\
\hline & 2nd entrance & Pass & Pass & Pass \\
\hline & 3rd entrance & Pass & Pass & Pass \\
\hline & 4th entrance & Pass & Pass & Pass \\
\hline \multirow[t]{4}{*}{ Glove Print UFC } & 1st entrance & 0 & 0 & 0 \\
\hline & 2nd entrance & 0 & 0 & 0 \\
\hline & 3rd entrance & 0 & 0 & 0 \\
\hline & 4th entrance & 0 & 0 & 0 \\
\hline \multirow[t]{4}{*}{ Settle plates UFC } & 1st entrance & 0 & 0 & 0 \\
\hline & 2nd entrance & 0 & 0 & 0 \\
\hline & 3rd entrance & 0 & 0 & 0 \\
\hline & 4th entrance & 0 & 0 & 0 \\
\hline TSB sterility test & $\begin{array}{l}\text { TSB used during the entire } \\
\text { procedure }\end{array}$ & Sterile & Sterile & Sterile \\
\hline
\end{tabular}

\section{HEK293T ongoing stability}

Thawing tests of the three batches of MCB and WCB showed an average of $94.2 \%$ and $95.3 \%$ of viability, respectively, indicating that the cryopreservation step did not affect cell viability. On the other hand, WCB 
cryovials were thawed periodically over a period of 37 months after cryopreservation. The viability over time was always superior to $50 \%$, thereby fulfilling specifications (Fig. 3A-3B). The cell number over time was always superior of 10 million cells per batch (Fig. 3C-3D). All together, these results confirmed the stability of the cell line 37 months after cryopreservation.

\section{Discussion}

In the present work we demonstrated the feasibility and difficulties of generating MCB and WCB under current GMP regulations ${ }^{15}$ in academic institutions. According to the current regulation, it is crucial to first implement a risk-based assessment of the whole process in order to thoroughly evaluate every stage of the manufacturing process such as cell culture growth, cell passages, quality control and IPCs requirements as well as evaluate the need of scale up procedures, in order to reach a minimum cell number per batch. Since the main objective of the risk-based assessment is to detect those risky steps which need mitigation actions for obtaining homogeneous and robust products. In this regard, it is important to carry out this evaluation by all key personnel involved in the manufacturing process such as quality control personnel, manufacturing personnel, quality assurance personnel and qualified person. The present work shows the approach established at Creatio to validate a GMP MCB and WCB of HEK293T cell line which are being used as packaging cells in GMP-grade lentivirus manufacturing used in several CAR T-cell clinical trials. ${ }^{11,19}$

One of the main changes that a research protocol undergoes when transferred to the clinic is the quality of the reagents and starting materials used. Frequently, new ATMPs developed in academic institutions use research-grade reagents and non-tested starting materials which do not fulfil the minimum quality required to start the manufacturing step. The HEK293T cell line is widely used in research as packaging cells in different viral-vector production system such as adeno-associated viruses (AAVs), retroviruses, adenoviruses (AD) or lentiviruses. ${ }^{20}$ For this reason, before using any cell line such as HEK293T, it is mandatory to analyze its quality parameters or attributes. In this regard, although according to Chap. 8 of the current GMP for ATMP manufacturing the generation of cell banks is not mandatory, ${ }^{15}$ it is highly recommended when they are going to intervene in manufacturing processes as starting materials, since this guarantees the robustness and homogeneity of products derived from them such as viral particles.

Sterility of three consecutive batches from the MCB and the subsequent WCB was analyzed. The results showed that all batches of HEK293T MCB and WCB were sterile. Due to the nature of ATMPs, which are considered as a live-products, sterility must be kept during the whole aseptic process. Accordingly, cleanrooms must be validated in order to guarantee the adequate environment in terms of viable and non-viable particles as well as the proper pressure, temperature and humidity of cleanrooms. In addition, a personnel training program which includes the aseptic simulation of the process should be established in every pharmaceutical quality system because personnel participating in the manufacturing process is considered to be the main focus of contamination. ${ }^{15}$ Creatio's personnel involved in MCB and WCB generation was successfully trained and validated to carry out the processes under current GMP 
guidelines. In addition, cleaning validation of Creatio facility was previously performed in order to guarantee and keep record of the cleaning process as a critical stage. Another critical aspect is the presence of mycoplasma in ATMPs or raw materials used in the ATMPs manufacturing. For this reason, mycoplasma test is a mandatory quality control test. According to the current GMP regulation for ATMPs manufacturing, ${ }^{15}$ the presence of mycoplasma in raw materials must be evaluated prior to starting the manufacturing process under a risk-based approach. The HEK293T initial stock was free of mycoplasma and the three consecutive batches of MCB and WCB were also free of this pathogen. In terms of safety, MCB and WCB must be also free of adventitious viruses. No cytopathic effect was detected in any batch, so we were able to ensure that the raw materials used in the manufacturing process and the handling of the cell cultures were not a focus of adventitious viruses.

Even though HEK293T cell line is never going to be used as a final product, it is necessary to characterize the identity of the cell line in order to guarantee its properties in biological terms such as growing time and packaging functions. In this sense, the presence of specific STRs after the MCB and WCB generation coincide with those given in the certificate of analysis of HEK293T cell line.Thus, no alteration of the STRs Amelogenin: X; CSF1PO: 11, 12; D13S317: 12, 14; D16S539: 9, 13; D5S818: 8, 9; D7S820: 11; TH01: 7, 9.3; TPOX: 11; VWA: 16, 18, 19 was detected after the passages performed during the processes. Moreover, karyotype was also analyzed in order to detect any alteration caused by the manipulation and the passages. HEK293T has a complex karyotype. Results from HEK293T MCB and WCB show a hypertriploid karyotype with numerous aberrant chromosomic alterations such as duplication and chromosomic derivation as described elsewhere. ${ }^{17,18}$ These results are mainly due to the genetic instability of this cell line. For this reason, karyotype specification does not have acceptance criteria and is considered to be informative. Nonetheless, we consider mandatory to document this information in order to track unexpected results of viral-vectors yields and correlate with chromosomic alterations.

Other crucial aspects when cell banking is being designed are the cryopreservation and storage conditions. ${ }^{21,22}$ HEK293T MCB and WCB were subjected to a cryopreservation ramp of $1{ }^{\circ} \mathrm{C} / \mathrm{min}$. Thawed cryovials showed cell viability over $90 \%$ indicating that cryopreservation did not affect the quality of the product. However, different cryopreservation ramps and different cryopreservation media should be evaluated when new cell lines are planned for banking. ${ }^{23}$ On the other hand, Creatio's cryopreservation tanks are designed to work under a gas phase liquid nitrogen that reduces cross-contamination and keeps the temperature more homogeneous than those working with liquid phase. Our results confirmed the long-term stability that cryopreserved HEK293T had over 37 months. With these data, we can assure that cell banking of HEK293T is an adequate approach to generate a homogeneous cellular product as well as to stablish an expiry date of GMP-MCB and GMP-WCB of 37 months, which can help researchers and manufactures to design ATMPs manufacturing protocols.

The present MCB and WCB approach shows the minimal requirements that academic institutions should bear in mind when a non-GMP cell line is used as starting material in a manufacturing process. Although the present work used an adherent cell line it would be equally possible to establish MCB/WCB of 
suspension cell lines following the same strategy. ${ }^{24-26}$ On the other hand, new technology is being developed for cell therapy products involving adherent or suspension cell culture. Bioreactors are emerging as closed systems which reduce reagent consumption and handling time. ${ }^{27,28}$ In this sense, the present procedure is applicable to generate cell banks from bioreactors systems. MCB and WCB approaches have been successfully performed in different ATMP manufacturing processes such as mesenchymal stem cells, ${ }^{29,30}$ fibroblasts, ${ }^{31}$ induced pluripotent stem cells or embryonic stem cells ${ }^{32,33}$ among others which have been used as a final product ready for administration. We would like to highlight the importance of GMP cell banking for ATMP manufacturing and its consideration for translational research.

\section{Conclusion}

The vast majority of ATMP require the use of specific cell lines as starting materials from which to generate cellular products or gene therapy products such as lentivirus or adenovirus. In this sense, the use of cell banks is a powerful tool that allows generating and preserving high quality cell lines. On the other hand, given that most of the knowledge about ATMP is generated in the academic scenario, it is crucial that researchers willing to develop new ATMP know the regulation that applies to their manufacturing processes. However, there is a general lack of information in the academia related to the ATMP regulation most commonly used in the pharmaceutical industry. This work presents a compatible approach with current GMP regulation that allows the scientific community to understand the process design and quality control test used for the HEK293T cell line MCB and WCB generation, which can be adapted to other manufacturing process.

\section{Abbreviations}

AAVs: Adeno-Associated Viruses

ADA-SCID: Adenosine Deaminase Deficiency

ALL: Acute Lymphoblastic Leukemia

ATMPs: Advanced Therapies Medicinal Products

BCMA: B Cell Maturation Antigen

CAR: Chimeric Antigen Receptor

CD: Cluster of Differentiation

DMSO: Dimethulsulphoxide

EMA: European Medicines Agency 
FBS: Fetal Bovine Serum

FDA: Food and Drug Administration

GMP: Good Manufacturing Practices

HBB: Hemoglobin Subunit Beta

HEK: Human Embryonic Kidney

IPCs: In Process Controls

MCB: Master Cell Bank

PBS: Phosphate-Buffered Saline

PCR: Polymerase Chain Reaction

rRNA: Ribosomal Ribonucleic Acid

SMA: Spinal Muscular Atrophy

SMN1: Survival Motor Neuron 1

STR: Short Tandem Repeats

STRs: Short Tandem Repeats

TSB: Tryptic Soy Broth media

WCB: Working Cell Bank

\section{Declarations}

Ethics approval and consent to participate

Not Applicable

Consent for publication

Not Applicable

Availability of data and materials

All data generated or analyzed during this study are included in this published article

Competing interests 
The authors declare that they have no competing interests

\section{Funding}

This study was supported by grants from the Ministerio de Ciencia, Innovación y Universidades (Spain), under project no. RTI2018-099001-B-I00 (JMC); Instituto de Salud Carlos III, Ministerio de Ciencia, Innovación y Universidades and European Regional Development Fund (ERDF) [RETICS (Red de Terapia Celular; RD16/0011/0012 to JMC)], Spain; Generalitat de Catalunya (2017SGR-1408 to JMC),Spain; and ADVANCE(CAT) with the support of ACCIÓ (Catalonia Trade \& Investment; Generalitat de Catalunya) and the European Community under the Catalonian ERDF operational program 2014-2020], Spain.

\section{Acknowledgements}

\section{Author Contributions}

UP and RM designed the experiments. $\mathrm{CH}$ and VM carried out the validation of manufacturing process. GO, EG, MO carried out Quality Control tests. MC, GS, AB carried out the stability tests. FC and UP review validations and GMP documentation. $A U, J D, M J$ critically read the manuscript. JMC coordinated and supervised the study.

\section{Declarations of interest:}

none.

\section{References}

1. Communities $\mathrm{C}$ of the E. Directive 2001/83/EC of the European Parliament and of the Council of 6 November 2001 on the Community code relating to medicinal products for human. of Eur Communities n.d.

2. Comission E. Regulation EC N 1394/2007 of the European Parliament and of The Council of 13 Nivember 2007 on advanced therapies medicinal products 2007.

3. Avivar-Valderas A, Martín-Martín C, Ramírez C, Del Río B, Menta R, Mancheño-Corvo P, et al. Dissecting allo-sensitization after local administration of human allogeneic adipose mesenchymal stem cells in perianal fistulas of Crohn's disease patients. Front Immunol 2019;10. https://doi.org/10.3389/fimmu.2019.01244.

4. Pellegrini G, Ardigò D, Milazzo G, lotti G, Guatelli P, Pelosi D, et al. Navigating Market Authorization: The Path Holoclar Took to Become the First Stem Cell Product Approved in the European Union. Stem Cells Transl Med 2018;7:146-54. https://doi.org/10.1002/sctm.17-0003.

5. Ginn SL, Amaya AK, Alexander IE, Edelstein M, Abedi MR. Gene therapy clinical trials worldwide to 2017: An update. J Gene Med 2018;20. https://doi.org/10.1002/jgm.3015.

6. What Is ZOLGENSMA® (onasemnogene abeparvovec-xioi) n.d. https://www.zolgensma.com/whatis-zolgensma (accessed May 4, 2020). 
7. Al-Zaidy SA, Mendell JR. From Clinical Trials to Clinical Practice: Practical Considerations for Gene Replacement Therapy in SMA Type 1. Pediatr Neurol 2019;100:3-11. https://doi.org/10.1016/j.pediatrneurol.2019.06.007.

8. Schuessler-Lenz M, Enzmann H, Vamvakas S. Regulators' Advice Can Make a Difference: European Medicines Agency Approval of Zynteglo for Beta Thalassemia. Clin Pharmacol Ther 2020;107:4924. https://doi.org/10.1002/cpt.1639.

9. Novartis N, Portfolio G, Data F. Novartis Receives First Ever FDA Approval for a CAR-T Cell Therapy, Kymriah (TM)(CTL019), for Children and Young Adults with B-cell ALL That Is Eefractory 2017.

10. Porter DL, Hwang WT, Frey N V., Lacey SF, Shaw PA, Loren AW, et al. Chimeric antigen receptor T cells persist and induce sustained remissions in relapsed refractory chronic lymphocytic leukemia. Sci Transl Med 2015;7. https://doi.org/10.1126/scitransImed.aac5415.

11. Castella M, Boronat A, Martín-Ibáñez R, Rodríguez V, Suñé G, Caballero M, et al. Development of a Novel Anti-CD19 Chimeric Antigen Receptor: A Paradigm for an Affordable CAR T Cell Production at Academic Institutions. Mol Ther - Methods Clin Dev 2019.

https://doi.org/10.1016/j.omtm.2018.11.010.

12. Brudno JN, Maric I, Hartman SD, Rose JJ, Wang M, Lam N, et al. T cells genetically modified to express an anti-B-Cell maturation antigen chimeric antigen receptor cause remissions of poorprognosis relapsed multiple myeloma. J Clin Oncol 2018;36:2267-80. https://doi.org/10.1200/JC0.2018.77.8084.

13. Ramos CA, Ballard B, Zhang H, Dakhova O, Gee AP, Mei Z, et al. Clinical and immunological responses after $\mathrm{CD} 30$-specific chimeric antigen receptor-redirected lymphocytes. J Clin Invest 2017;127:3462-71. https://doi.org/10.1172/JCI94306.

14. Meij P, Canals J, Lowery M, Scott M. Advanced Therapy Medicinal Products. n.d.

15. EudraLex The Rules Governing Medicinal Products in the European Union Volume 4 Good Manufacturing Practice Guidelines on Good Manufacturing Practice specific to Advanced Therapy Medicinal Products Document History. n.d.

16. European Pharmacopoeia (Ph. Eur.) 10th Edition I EDQM - European Directorate for the Quality of Medicines n.d. https://www.edqm.eu/en/european_pharmacopoeia_10th_edition (accessed May 4, 2020).

17. Stepanenko AA, Dmitrenko V V. HEK293 in cell biology and cancer research: Phenotype, karyotype, tumorigenicity, and stress-induced genome-phenotype evolution. Gene 2015;569:182-90. https://doi.org/10.1016/j.gene.2015.05.065.

18. Lin YC, Boone M, Meuris L, Lemmens I, Van Roy N, Soete A, et al. Genome dynamics of the human embryonic kidney 293 lineage in response to cell biology manipulations. Nat Commun 2014;5. https://doi.org/10.1038/ncomms5767.

19. Castella M, Caballero-Baños M, Ortiz-Maldonado V, González-Navarro EA, Suñé G, Antoñana-Vidósola A, et al. Point-Of-Care CAR T-Cell Production (ARI-0001) Using a Closed Semi-automatic Bioreactor: 
Experience From an Academic Phase I Clinical Trial. Front Immunol 2020;11:482. https://doi.org/10.3389/FIMMU.2020.00482.

20. Van Der Loo JCM, Wright JF. Progress and challenges in viral vector manufacturing 2015. https://doi.org/10.1093/hmg/ddv451.

21. Li Y, Ma T. Bioprocessing of cryopreservation for large-scale banking of human pluripotent stem cells. Biores Open Access 2012;1:205-14. https://doi.org/10.1089/biores.2012.0224.

22. Shafa M, Walsh T, Panchalingam KM, Richardson T, Menendez L, Tian X, et al. Long-term stability and differentiation potential of cryopreserved cGMP-compliant human induced pluripotent stem cells. Int J Mol Sci 2020;21. https://doi.org/10.3390/ijms21010108.

23. Martín-Ibáñez R, Hovatta O, M. J. Cryopreservation of Human Pluripotent Stem Cells: Are We Going in the Right Direction? Curr. Front. Cryobiol., InTech; 2012. https://doi.org/10.5772/34853.

24. Olmer R, Lange A, Selzer S, Kasper C, Haverich A, Martin U, et al. Suspension culture of human pluripotent stem cells in controlled, stirred bioreactors. Tissue Eng - Part C Methods 2012;18:772-84. https://doi.org/10.1089/ten.tec.2011.0717.

25. Zweigerdt R, Olmer R, Singh H, Haverich A, Martin U. Scalable expansion of human pluripotent stem cells in suspension culture. Nat Protoc 2011;6:689-700. https://doi.org/10.1038/nprot.2011.318.

26. Kwok CK, Ueda Y, Kadari A, Günther K, Ergün S, Heron A, et al. Scalable stirred suspension culture for the generation of billions of human induced pluripotent stem cells using single-use bioreactors. $J$ Tissue Eng Regen Med 2018;12:e1076-87. https://doi.org/10.1002/term.2435.

27. Valkama AJ, Leinonen HM, Lipponen EM, Turkki V, Malinen J, Heikura T, et al. Optimization of lentiviral vector production for scale-up in fixed-bed bioreactor. Gene Ther 2018;25:39-46. https://doi.org/10.1038/gt.2017.91.

28. Leinonen HM, Lipponen EM, Valkama AJ, Hynynen H, Oruetxebarria I, Turkki V, et al. Preclinical Proofof-Concept, Analytical Development, and Commercial Scale Production of Lentiviral Vector in Adherent Cells. Mol Ther - Methods Clin Dev 2019;15:63-71.

https://doi.org/10.1016/j.omtm.2019.08.006.

29. Lechanteur C, Briquet A, Giet O, Delloye O, Baudoux E, Beguin Y. Clinical-scale expansion of mesenchymal stromal cells: A large banking experience. J Transl Med 2016;14:145. https://doi.org/10.1186/s12967-016-0892-y.

30. Cooper K, Viswanathan C. Establishment of a Mesenchymal Stem Cell Bank. Stem Cells Int 2011;2011. https://doi.org/10.4061/2011/905621.

31. Prathalingam N, Ferguson L, Young L, Lietz G, Oldershaw R, Healy L, et al. Production and validation of a good manufacturing practice grade human fibroblast line for supporting human embryonic stem cell derivation and culture. Stem Cell Res Ther 2012;3. https://doi.org/10.1186/scrt103.

32. Devito L, Petrova A, Miere C, Codognotto S, Blakely N, Lovatt A, et al. Cost-Effective Master Cell Bank Validation of Multiple Clinical-Grade Human Pluripotent Stem Cell Lines From a Single Donor. Stem Cells Transl Med 2014;3:1116-24. https://doi.org/10.5966/sctm.2014-0015. 
33. Shafa M, Yang F, Fellner T, Rao MS, Baghbaderani BA. Human-induced pluripotent stem cells manufactured using a current good manufacturing practice-compliant process differentiate into clinically relevant cells from three germ layers. Front Med 2018;5:69. https://doi.org/10.3389/fmed.2018.00069.

\section{Figures}

Figure 1

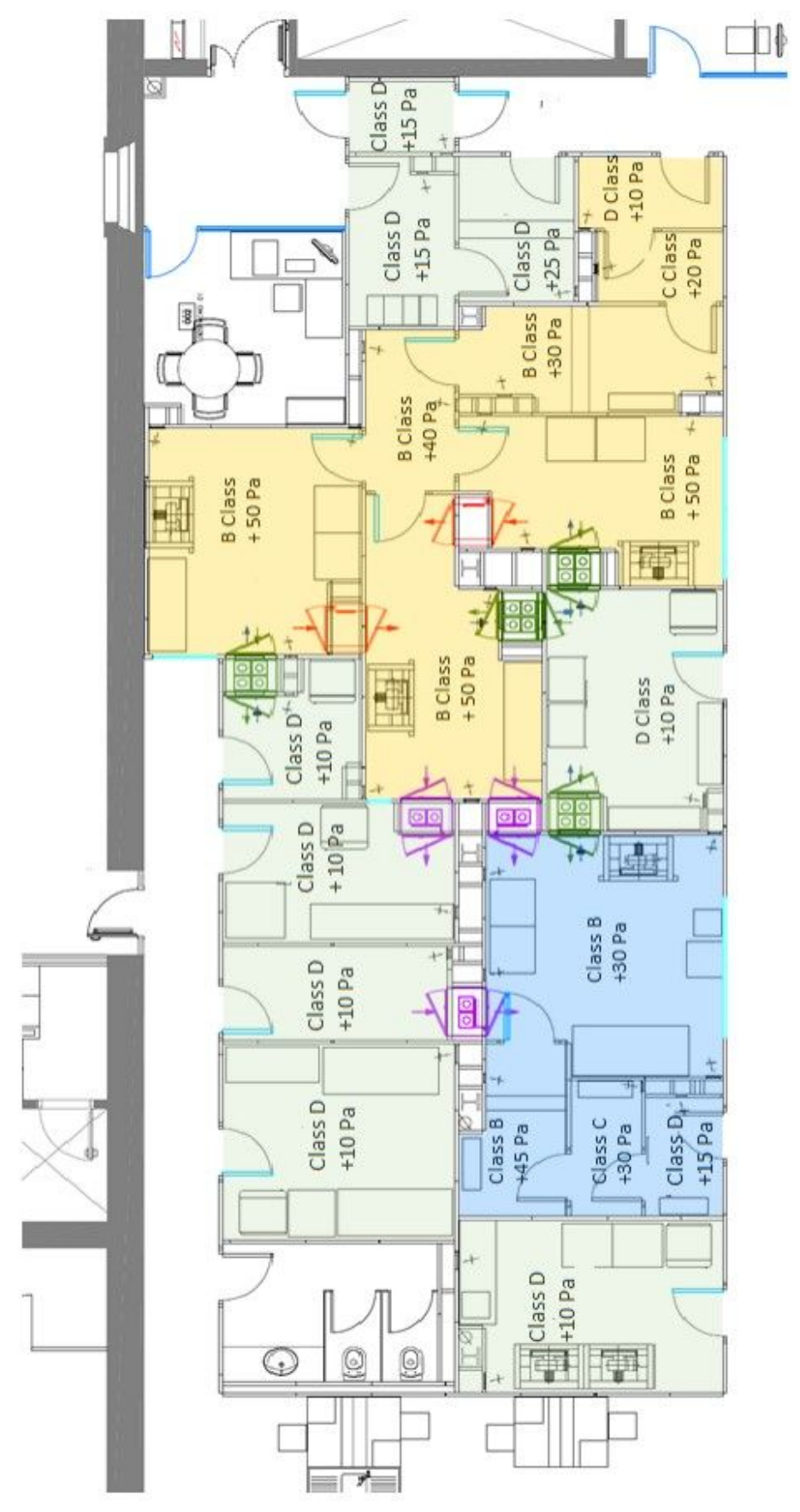




\section{Figure 1}

Layout of Creatio GMP facility. Facility is controlled by three independent HVAC (orange, blue and green). In white, non-classified areas. In orange, HVAC-1. In blue, HVAC-2. In green, HVAC-3. The rooms belonging to the HVAC-3 have a pressure of $10 \mathrm{~Pa}$ and are dedicated to product storage, product conditioning. Cell therapy products are manufactured in HVAC-1. Cleanrooms (B-grade) belonging to HVAC-1 have a pressure of $50 \mathrm{~Pa}$, adjacent rooms have a differential pressure of $10-15 \mathrm{~Pa}$. HVAC-2 is dedicated to gene therapy products. Access to cleanroom (B-grade) are composed by dressing rooms which have a differential pressure of 10-15 $\mathrm{Pa}$. B-grade cleanroom is under pressured (30 Pa) from the adjacent dressing room $(40 \mathrm{~Pa})$ as a physical containment barrier. 


\section{Figure 2}

A

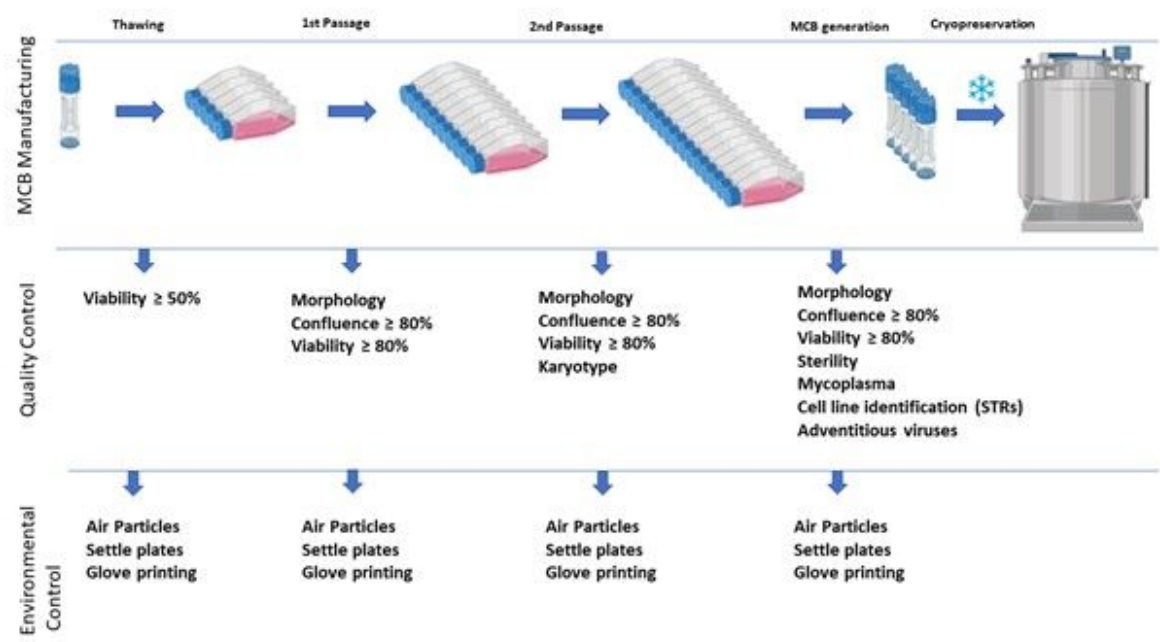

B

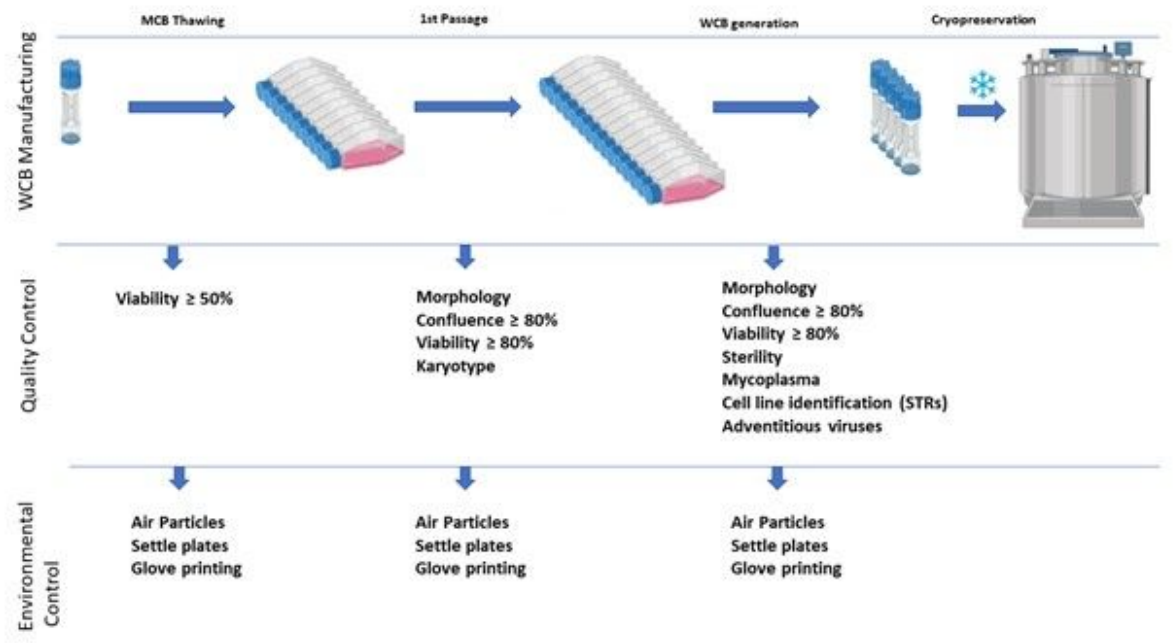

\section{Figure 2}

A MCB workflow. MCB was composed by 3 independent batches equal or greater than 20 cryotubes/batch. HEK293T cell line cryovial was thawed and expanded until reaching 200.106 of cells. Two cell passages were needed to obtain the $200 \cdot 106$ of cells. After the second passage cells were conditioned in cryotubes in a rate of 10.106 of cells per tube and cryopreserved following a freezing program that lowers the temperature $1^{\circ} \mathrm{C} /$ minute. MCB cryotubes were transferred to a gas phase 
nitrogen tank $180^{\circ} \mathrm{C} \pm 20^{\circ} \mathrm{C}$. WCB was composed by 3 independent batches equal or greater than 50 cryotubes/batch. Environmental controls, IPCs of each cell passage and quality control test of the final product are represented in the image. B WCB workflow. MCB HEK293T cryovial was thawed and expanded until reaching $1000 \cdot 106$ of cells. One cell passage was needed to obtain the $1000 \cdot 106$ of cells. Cells were conditioned in cryotubes in a rate of 20.106 of cells per tube and cryopreserved following a freezing program that lowers the temperature $1^{\circ} \mathrm{C}$ /minute. WCB cryotubes were transferred to a gas phase nitrogen tank $180^{\circ} \mathrm{C} \pm 20^{\circ} \mathrm{C}$. Environmental controls, IPCs of each cell passage and quality control test of the final product are represented in the image. 
Figure 3

A

\begin{tabular}{|c|c|}
\hline $\begin{array}{l}\text { Month after } \\
\text { cryopreservation }\end{array}$ & Cell Viability (\%) \\
\hline 2 & 92.5 \\
\hline 3 & 93.4 \\
\hline 4 & 96 \\
\hline 13 & 78 \\
\hline 17 & 89.8 \\
\hline 18 & 96 \\
\hline 19 & 95 \\
\hline 23 & 96.5 \\
\hline 24 & 97.3 \\
\hline 26 & 97.2 \\
\hline 27 & 94.5 \\
\hline 28 & 96.2 \\
\hline 30 & 96 \\
\hline 32 & 97.5 \\
\hline 33 & 95.2 \\
\hline 37 & 91.8 \\
\hline
\end{tabular}

C

\begin{tabular}{|c|c|}
\hline $\begin{array}{c}\text { Month after } \\
\text { cryopreservation }\end{array}$ & $\begin{array}{c}\text { Cell } \\
\text { number/cryotube }\end{array}$ \\
\hline 2 & $1.75 \mathrm{E}+07$ \\
\hline 3 & $1.40 \mathrm{E}+07$ \\
\hline 4 & $1.45 \mathrm{E}+07$ \\
\hline 13 & $1.10 \mathrm{E}+07$ \\
\hline 17 & $1.88 \mathrm{E}+07$ \\
\hline 18 & $1.88 \mathrm{E}+07$ \\
\hline 19 & $1.90 \mathrm{E}+07$ \\
\hline 23 & $1.40 \mathrm{E}+07$ \\
\hline 24 & $1.85 \mathrm{E}+07$ \\
\hline 26 & $1.83 \mathrm{E}+07$ \\
\hline 27 & $2.63 \mathrm{E}+07$ \\
\hline 28 & $1.90 \mathrm{E}+07$ \\
\hline 30 & $1.80 \mathrm{E}+07$ \\
\hline 32 & $1.98 \mathrm{E}+07$ \\
\hline 33 & $1.56+\mathrm{E} 07$ \\
\hline 37 & $1.38 \mathrm{E}+07$ \\
\hline
\end{tabular}

B

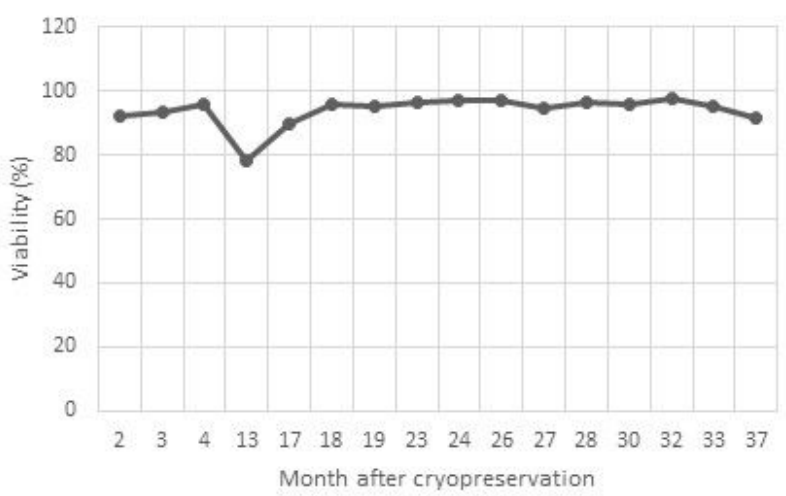

D

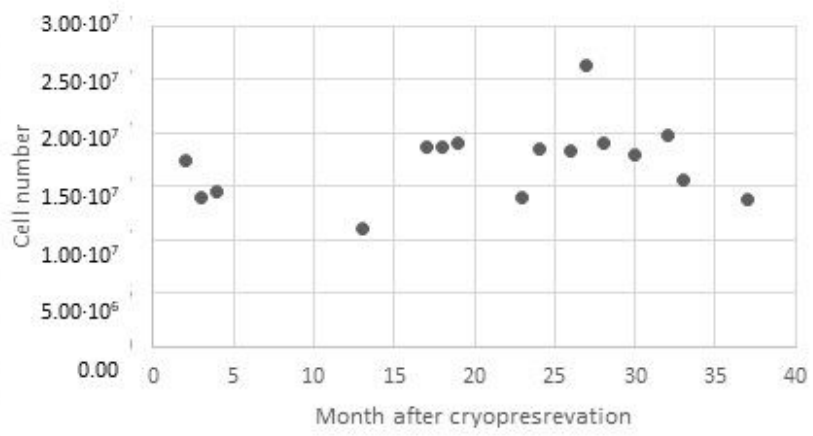

\section{Figure 3}

Stability program of the WCB. A. Table showing the viability obtained after thawing WCB cryovials during a period of 37 months. B. Graph representing the viability after thawing WCB cryovials during a period of 37 months after the cryopreservation of the WCB. C. Table showing the cell number obtained after thawing WCB cryovials during a period of 37 months. D. Graph representing the cell number after thawing WCB cryovials during a period of 37 months after the cryopreservation of the WCB. 